been suggested that viruses may cause this condition, and small virus-like particles were seen in the colonic exudate, similar to those reported in rectal biopsy findings. ${ }^{3}$ These particles, however, have also been observed in other unrelated conditions and in normal tissue. ${ }^{6} 89$

Pathological studies have suggested a locally acting toxic agent. ${ }^{156}$ We think the toxin we found in tissue culture tests on suspensions of faecal exudate is related to the disease. It was present at surprisingly high dilutions of faeces and tissue biopsy suspension, disappearing when the patient recovered. The cytopathic effect was quite distinct from the cell granularity and degeneration often seen after inoculation of stool specimens into tissue culture for the isolation of viruses. It was not found in stools from a wide variety of other intestinal disorders. Many questions still remain unanswered and we propose to investigate further the properties of the toxin and its occurrence in this disease and in antibiotic-induced diarrhoea.

We could not find the source of this cytotoxin in a preliminary screening of the bacteria isolated, but special in-vivo conditions may be required for its production. It might result from tissue breakdown or inflammation, though we have not found it in other cases of infective diarrhoea or inflammatory bowel disease. Since pseudomembranous colitis is uncommon we hope this preliminary report will encourage others to look for similar tissue culture effects in the disease. If it is proved to be caused by a bacterial toxin then it may become possible to treat it with specific antibacterial measures.

We thank Sir Graham Bull for referring the patient, Drs $R$ Dourmashkin and $S$ Patterson for help with electron microscopy, and Dr C Hawkey for immunological studies.

\section{References}

1 Goulston, S J M, and McGovern, V J, Gut, 1965, 6, 212.

2 Keusch, G T, and Present, D H, Fournal of Infectious Diseases, 1976, 133, 578.

3 Steer, H W, Gut, 1975, 16, 695.

4 Whitehead, R, Gut, 1971, 12, 912.

${ }^{5}$ Price, A B, and Davies, D R, fournal of Clinical Pathology, 1977, 30, 3.

6 Pittmann, F E, et al, Archives of Internal Medicine, 1974, 134, 368.

7 Marr, J J, et al, Gastroenterology, 1975, 69, 352.

8 Dourmashkin, $\mathrm{R}$, personal communication.

o Owen, R L, Gastroenterology, 1976, 70, 1185.

(Accepted 8 March 1977)

\title{
Comparative trial of endocrine versus cytotoxic treatment in advanced breast cancer
}

\author{
T PRIESTMAN, M BAUM, VERA JONES, J FORBES
}

British Medical fournal, 1977, 1, 1248-1250

\section{Summary}

Ninety-two women with advanced breast cancer were allocated at random to receive either cytotoxic or endocrine treatment. Out of 45 women included in the cytotoxic treatment group, $22(49 \%)$ achieved complete or partial remission of their disease, whereas of the 47 included in the endocrine treatment group, only 10 $(21 \%)$ achieved such remission. Significantly longer survival times in the cytotoxic treatment group were most apparent among premenopausal women, $75 \%$ of such patients responding to cytotoxic drugs (median survival 46 weeks) compared with only $11 \%$ benefiting from ovarian ablation (median survival 12 weeks). In postmenopausal women with predominantly soft-tissue disease, however, additive hormonal treatment with tamoxifen produced remission rates and survival times equivalent to those produced by cytotoxic drugs.

Cardiff Breast Clinic, Velindre Hospital, Cardiff CF4 7XL

T PRIESTMAN, MRCP, FRCR, consultant in radiotherapy and oncology (present address: Wellcome Research Laboratories, Beckenham, Kent) VERA JONES, MB, BS, medical assistant

Surgical Unit, University Hospital of Wales, Cardiff

M BAUM, MCHIR, FRCS, senior lecturer

J FORBES, MS, FRCS, Nuffield fellow in surgery

\section{Introduction}

In Britain doctors still generally accept that the first line of management for recurrent or metastatic breast cancer is endocrine treatment and that cytotoxic drugs have only a secondary role. Various investigators have reported remarkably good results using combination cytotoxic treatment in late breast cancer in recent years, ${ }^{1-3}$ and some have suggested that traditional endocrine measures may have little further part to play. Many such results have come from uncontrolled series, which, combined with arguments that the side effects of cytotoxic treatment are greater and the duration of remission is shorter than with endocrine treatment, has reduced the credibility of the chemotherapists' claims. We therefore decided to design a prospective trial comparing these two approaches to management.

\section{Patients and methods}

All women with locally recurrent or metastatic adenocarcinoma of the breast who had not received previous systemic treatment were admitted to the study provided that they had clinically or radiologically assessable disease. By means of treatment cards drawn from sequentially numbered sealed envelopes they were allocated at random to receive appropriate endocrine treatment or combination cytotoxic therapy. The policy of endocrine treatment adopted evolved from the following considerations.

Premenopausal women and those within two years of their last menstrual period underwent either oophorectomy or induction of menopause by radiation. In a previous study at the Cardiff Breast Clinic oestrogen, androgen, and progesterone treatments were compared in postmenopausal women with breast cancer. ${ }^{5}$ Patients with secondary deposits predominantly in bone responded best to androgens, and those with secondary deposits in soft tissue or lung parenchyma responded particularly well to stilboestrol. A later study in Cardiff looked at tamoxifen treatment in women who were 
two or more years postmenopausal. The overall response rate was $35 \%$, women with soft-tissue disease faring particularly well. ${ }^{\circ}$ Although these two studies were not strictly comparable, the response to tamoxifen was encouraging when contrasted with the previous series, especially in view of the minimal toxicity of tamoxifen. For postmenopausal patients with predominantly hepatic involvement or lymphangitis carcinomatosa personal experience, and that of others, ${ }^{7}$ suggested that steroids would be the best form of treatment. These treatment subgroups and the regimens chosen are summarised in table I.

TABLE I-Treatment regimens used in study

\begin{tabular}{|c|c|c|}
\hline Subgroup & Endocrine & Cytotoxic \\
\hline $\begin{array}{l}\text { Postmenopausal with secon- } \\
\text { dary deposits in lung par- } \\
\text { enchyma .. } \\
\text { Postmenopausal with liver } \\
\text { involvement or lymphang- } \\
\text { itis carcinomatosa }\end{array}$ & $\begin{array}{l}\text { Ovarian ablation } \\
\text { Tamoxifen } 20 \mathrm{mg} \text { twice } \\
\text { daily } \\
\text { Methyltestosterone } 5 \mathrm{mg} \\
\text { thrice daily + nandro- } \\
\text { lone phenylpropionate } \\
50 \mathrm{mg} \text { intramuscularly } \\
\text { once weekly } \\
\text { Stilboestrol } 5 \mathrm{mg} \text { thrice } \\
\text { daily } \\
\text { Prednisone } 10 \mathrm{mg} \text { thrice } \\
\text { daily }\end{array}$ & $\begin{array}{c}\text { Doxorubicin } 60 \mathrm{mg} \\
\text { plus } \\
\text { cyclophosphamide } \\
750 \mathrm{mg} \\
\text { plus } \\
\text { fluorouracil } 750 \mathrm{mg} \\
\text { plus } \\
\text { vincristine } 2 \mathrm{mg} \\
\text { by intravenous injection } \\
\text { on one day every three } \\
\text { weeks }\end{array}$ \\
\hline
\end{tabular}

Table I also shows cytotoxic regimen chosen. The preliminary studies that led to the choice of this regimen have already been reported. ${ }^{8}$ Patients in the cytotoxic treatment group who achieved a complete remission and were still experiencing nausea were allowed to change to an oral maintenance regimen six months after starting treatment. At each attendance the white blood cell count was monitored, and if this fell below $9 \times 10^{9} / 1\left(3000 / \mathrm{mm}^{3}\right)$ the dose of cytotoxic agents was reduced. To prevent cardiac toxicity the dose of doxorubicin was limited to $400 \mathrm{mg}$.

The criteria of objective response were those recommended by the UICC. ${ }^{9}$ Complete response indicated total regression of all assessable disease, sustained for at least three months; and partial response, more than $50 \%$ regression. In analysing the results, patients who achieved a complete or partial response were regarded as successes, and those in whom the disease was static or progressed were regarded as failures. Subjective response was measured by linear analogue selfassessment, "1 the results of which will be reported separately.

\section{Results}

\section{OVERALL RESULTS}

Out of 100 patients admitted to the study, 92 were available for assessment. Of these, 47 were included in the endocrine treatment group and 45 in the cytotoxic treatment group. The overall response rates in the two groups are shown in table II. Cytotoxic treatment produced significantly more responses than endocrine treatment ( $P<0.02 ; \gamma^{2}$ test with Yates's correction for small numbers) despite the cytotoxic group containing a higher proportion of patients with generalised disease. The remission rate in the cytotoxic treatment group was the same for patients with local and generalised disease, in contrast to the endocrine series. The median duration of remission in patients responding to endocrine treatment was $29+$ weeks, and in patients responding to cytotoxic treatment $32+$ weeks. The actuarial survival curves for the two groups are shown in the figure. Survival in the cytotoxic group was significantly better than in the endocrine group $(\mathrm{P}<0.015$; Peto log rank test $)$. At the time of review $29(64 \%)$

TABLE $\mathrm{II}-($ )verall results in the two treatment groups

\begin{tabular}{|c|c|c|c|c|c|c|}
\hline \multirow{2}{*}{$\begin{array}{l}\text { Treatment } \\
\text { group }\end{array}$} & \multicolumn{2}{|c|}{ Local disease } & \multicolumn{2}{|c|}{ General disease } & \multicolumn{2}{|c|}{ Total } \\
\hline & $\begin{array}{l}\text { No of } \\
\text { cases }\end{array}$ & $\begin{array}{l}\text { No (".) } \\
\text { responding }\end{array}$ & $\begin{array}{l}\text { No of } \\
\text { cases }\end{array}$ & $\begin{array}{l}\text { No ( }\left("{ }_{0}\right) \\
\text { responding }\end{array}$ & $\begin{array}{l}\text { No of } \\
\text { cases }\end{array}$ & $\begin{array}{l}\left.\text { No (" }{ }^{\prime \prime)}\right) \\
\text { responding }\end{array}$ \\
\hline $\begin{array}{l}\text { Endocrine.. } \\
\text { Cytotoxic . }\end{array}$ & $\begin{array}{l}23 \\
14\end{array}$ & $\begin{array}{l}8(35) \\
7(50)\end{array}$ & $\begin{array}{l}24 \\
31\end{array}$ & $\begin{array}{c}2(8) \\
15(48)\end{array}$ & $\begin{array}{l}47 \\
45\end{array}$ & $\begin{array}{l}10(21) \\
22(49)\end{array}$ \\
\hline
\end{tabular}

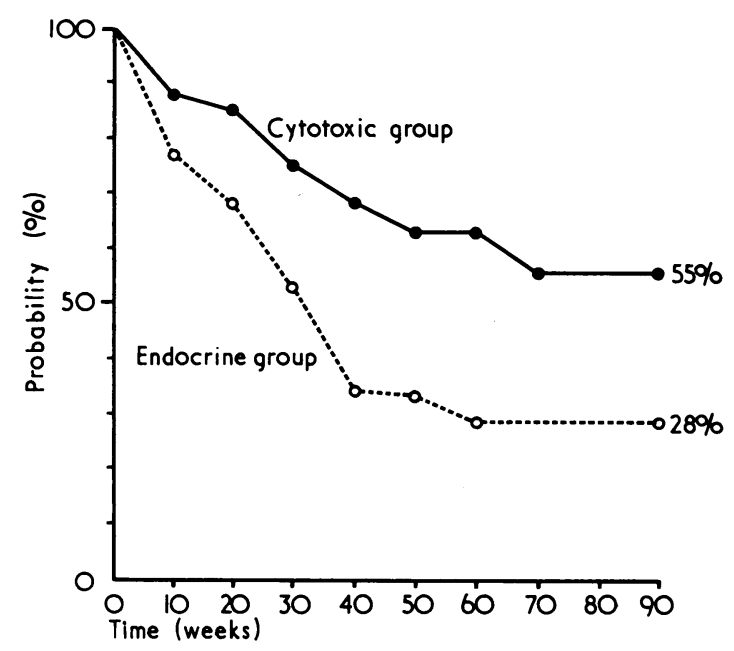

Actuarial survival curves for the two treatment groups.

of the patients in the cytotoxic treatment group were alive compared with only $19(40 \%)$ of those in the endocrine treatment group. The influence of the disease-free interval, as measured from the time cancer was diagnosed to the first appearance of recurrence or metastasis, on the response rate is shown in table III.

TABLE III-Disease-free interval (DFI) and response to treatment in the two groups

\begin{tabular}{|c|c|c|c|c|c|c|}
\hline \multirow{2}{*}{$\begin{array}{l}\text { Treatment } \\
\text { group }\end{array}$} & \multicolumn{2}{|c|}{$\begin{array}{l}\text { Advanced disease on } \\
\text { presentation }\end{array}$} & \multicolumn{2}{|c|}{$\begin{array}{l}\text { DFI less than } \\
\text { two years }\end{array}$} & \multicolumn{2}{|c|}{$\begin{array}{l}\text { DFI more than } \\
\text { two years }\end{array}$} \\
\hline & $\begin{array}{l}\text { No of } \\
\text { cases }\end{array}$ & $\begin{array}{c}\text { No }\left({ }_{0}^{0}\right) \\
\text { responding }\end{array}$ & $\begin{array}{l}\text { No of } \\
\text { cases }\end{array}$ & $\begin{array}{l}\text { No }(\%) \\
\text { responding }\end{array}$ & $\begin{array}{l}\text { No of } \\
\text { cases }\end{array}$ & $\begin{array}{c}\text { No (\%) } \\
\text { responding }\end{array}$ \\
\hline $\begin{array}{l}\text { Endocrine.. } \\
\text { Cytotoxic .. }\end{array}$ & $\begin{array}{r}13 \\
8\end{array}$ & $\begin{array}{l}1(8) \\
6(75)\end{array}$ & $\begin{array}{l}19 \\
24\end{array}$ & $\begin{array}{r}3(16) \\
10(42)\end{array}$ & $\begin{array}{l}15 \\
13\end{array}$ & $\begin{array}{l}6(40) \\
6(46)\end{array}$ \\
\hline
\end{tabular}

\section{PREMENOPAUSAL PATIENTS}

Nine patients were treated by ovarian ablation, seven by oophorectomy, and two by radiation-induced menopause. (One patient underwent radiation therapy after refusing operation, and the other was unfit for anaesthesia.) Only one of the nine patients treated by ovarian ablation gained an objective response compared with nine out of 12 patients given chemotherapy. This difference was significant ( $P=0.012$; Fisher's tables for exact test). Only three patients in the endocrine treatment group had generalised disease, whereas 10 patients in the cytotoxic treatment group had overt blood-borne metastases. The median duration of remission in the cytotoxic treatment group was $34+$ weeks. The median survival time in the endocrine treatment group was $12+$ weeks, and in the cytotoxic treatment group $46+$ weeks.

\section{POSTMENOPAUSAL PATIENTS WITH PREDOMINANTLY SOFT-TISSUE DISEAS}

This group consisted of 47 patients, and it was decided to consider separately perimenopausal women (within two to five years of their last menstrual period) and late postmenopausal patients.

Thirty-four women were more than five years postmenopausal. Of those treated with tamoxifen, nine out of $22(41 \%)$ gained an objective response, and in the cytotoxic treatment group six out of 12 responded. In this subgroup the difference in response rate was not significant and the median survival times were similar $(34+$ weeks for those receiving tamoxifen, $37+$ weeks for those receiving cytotoxic drugs), although at the time of review the median duration of remission was longer in the cytotoxic treatment group $(55+$ weeks compared with $34+$ weeks). Although soft-tissue recurrence or metastases were the dominant problem in these patients, pretreatment investigation showed asymptomatic bone metastases in five patients in the endocrine group and six in the cytotoxic treatment group. 
Of these, two patients receiving tamoxifen and four in the cytotoxic group were among the responders, in each instance improvement in local disease being accompanied by radiological evidence of bone healing.

In the perimenopausal group none of the four patients receiving tamoxifen responded but five out of nine women given cytotoxic treatment gained objective benefit, the median duration of their remission being $29+$ weeks. The numbers were too small for statistical analysis, and in addition the endocrine group was at a disadvantage in that three of the four patients had asymptomatic bone metastases, whereas only three of the nine in the cytotoxic treatment group had this problem.

\section{PREDOMINANTLY BONE, LUNG, OR LIVER DISEASE}

There were too many small subdivisions in this subgroup of 24 patients to allow meaningful analysis. The overall results of treatment were disappointing (only two objective responses, both with cytotoxic treatment) (table IV).

TABLE IV-Response rate in individual subgroups

\begin{tabular}{|c|c|c|c|c|}
\hline \multirow[b]{2}{*}{ Subgroup } & \multicolumn{2}{|c|}{ Endocrine treatment } & \multicolumn{2}{|c|}{ Cytotoxic treatment } \\
\hline & $\begin{array}{l}\text { No of } \\
\text { cases }\end{array}$ & $\begin{array}{c}\text { No (o\%) } \\
\text { responding }\end{array}$ & $\begin{array}{l}\text { No of } \\
\text { cases }\end{array}$ & $\begin{array}{l}\text { No }\left(0_{0}^{\prime}\right) \\
\text { responding }\end{array}$ \\
\hline 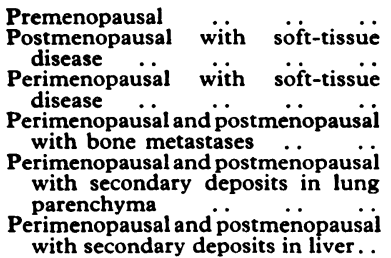 & $\begin{array}{r}9 \\
22 \\
4\end{array}$ & $\begin{array}{l}1(11) \\
9(41)\end{array}$ & 12 & $\begin{array}{l}9(75) \\
6(50) \\
5(56) \\
1(25) \\
1(50)\end{array}$ \\
\hline
\end{tabular}

\section{SIDE EFFECTS}

Nausea and alopecia were invariable complications of cytotoxic treatment. The degree of nausea varied greatly with different patients, but the only woman to refuse treatment because of vomiting was receiving stilboestrol. Alopecia was temporary, and women continuing with aggressive chemotherapy grew a full head of hair within a year. No patient developed such haematological toxicity that treatment had to be stopped.

\section{Discussion}

When designing this prospective trial a major problem was encountered in selecting the type of endocrine treatment to be used. The ideal would have been to employ a single endocrine agent or ablative manoeuvre to compare with the chemotherapeutic regimen but no one endocrine procedure is appropriate for all clinical presentations of advanced breast cancer. An optimum strategy of endocrine treatment had been evolved in the Cardiff Breast Clinic over many years of sequential trials, and we felt that this strategy should be compared with one of the most effective chemotherapeutic regimens available.

Perhaps the most striking result of this study was the poor overall performance of endocrine treatment, except for tamoxifen in postmenopausal women with localised disease. The results reported appear to be worse than in previous studies in our department and most other reported series. The most likely explanation for this difference is our application of the strictest criteria of response, though the same criteria applied to both the endocrine-treated and cytotoxic-treated patients. The results in the latter group were also disappointing compared with other reported series. An alternative explanation, for which there is no strong scientific evidence, is that the nature of the disease is changing, so that we are now seeing fewer endocrine-sensitive tumours than before.

Ovarian ablation, which is the least controversial and best established therapeutic measure for advanced breast cancer in premenopausal women, produced surprisingly poor results. Most women in the ovarian ablation group, however, had local disease, and these patients may do less well after oophorectomy than those with disseminâtea ${ }^{-}$disease. ${ }^{11}$ Furthermore, although the difference in response rate compared with those women given cytotoxic drugs was highly significant, the order of difference might have been exaggerated because of the relatively small numbers. There is therefore an urgent need for this study to be repeated on premenopausal women only.

With the development of oestradiol-receptor assays it was hoped to put the treatment of breast cancer on a rational basis by selecting out those tumours that were likely to be endocrineresponsive from those that were likely to be autonomous. There are two problems with this approach. The first is to obtain enough tumour for assays. This is easy when there is extensive soft-tissue disease but almost impossible when one is dealing with patients with bony metastases or parenchymal lung disease, such patients constituting nearly half the total in this study. Secondly, when material is available for receptor assays, then even if the results are positive the response rate to endocrine treatment is still of the order of $50-60 \% 0^{12}$

We may reasonably conclude from our results that, overall, combination cytotoxic drug treatment is more likely to produce a response and to prolong life than immediate endocrine treatment for advanced breast cancer. Furthermore, this becomes an urgent consideration with premenopausal women, in whom chemotherapy delayed until the failure of ovarian ablation has been shown does not seem capable of salvaging lives. The only subgroup in which endocrine measures appeared to be equivalent to cytotoxic drug treatment was that of postmenopausal women with premoninantly soft-tissue disease. In this case one would clearly wish to advocate tamoxifen rather than chemotherapy because of its ease of administration, lack of side effects, and relatively low cost.

Finally, when comparing two such varying regimens the quality of life must be an important consideration. In parallel with the objective criteria of response a prospective study of subjective response has also been conducted and will form the basis of a subsequent communication. The one fact, however, that stands out from this study is that when patients themselves see the benefit of their treatment they accept the side effects. When there is no such detectable benefit then the side effects of treatment become intolerable.

We thank Mr C Smith for advice on medical statistics, and Dr D K L Davies for evaluating the radiographs.

\section{References}

${ }^{1}$ Cooper, R G, Proceedings of the American Association for Cancer Research, $1969,10,15$.

2 Edelstyn, G J A, Vinca Alkaloids in Chemotherapy of Malignant Disease. London, Lilly, 1972.

${ }^{3}$ Hanham, I W F, Newton, K A, and Westbury, G, British fournal of Cancer, 1971, 25, 462.

+ Edelstyn, G J A, and Macrae, K D, British fournal of Cancer, 1973, 28, 459.

5 Jones, V, in Clinical Management of Advanced Breast Cancer, ed C A F Joslin and E N Gleave. Cardiff, Tenovus, 1970.

6 Jones, V, and Henk, J M, personal communication, 1974.

7 Stoll, B, in Endocrine Therapy in Malignant Disease. London, Saunders, 1972.

${ }^{8}$ Priestman, T J, Clinical Oncology, 1975, 1, 207.

- Hayward, J L, et al, European fournal of Cancer. In press.

10 Priestman, T J, and Baum, M, Lancet, 1976, 1, 899.

11 Taylor, S G, Surgery, Gynecology and Obstetrics, 1962, 115, 443.

${ }^{12}$ Leung, B S, Krippaehne, W W, and Fletcher, W S, Surgery, Gynecology and Obstetrics, 1974, 139, 525.

(Accepted 24 February 1977) 